\title{
Blog jako gatunek tekstu w kontekście monetyzacji treści
}

\begin{abstract}
Streszczenie
Blog to gatunek hipertekstowy o dużej rozpiętości wzorca pod względem strukturalnym, pragmatycznym, poznawczym i stylistycznym. Wynika to z jego krótkiej historii i dużych zmian u komunikacji internetowej. Autor bloga musi publikować artykuły regularnie przez długi czas, aby zarabiać dzięki niemu. Wprowadza wiele modyfikacji do uzorca gatunkouego, aby dopasować je do prowadzonych przez siebie działań. Najwyraźniejsze zmiany dotyczą struktury gatunku i polegają na dodawaniu reklam, artykułów sponsorowanych, linków aktywacyjnych oraz osobnych kart na stronie internetowej (np. szkolenia, warsztaty, obozy czy sklep). Zauważa się duży upływ reklamodawców lub zleceniodawców, którzy pośrednio biorą udział w procesie tworzenia tekstu i przyjmują rolę kontrolera przekazu. Przekaz autorski częściej niż na innych blogach przyjmuje charakter persuazyjny, by promować własną działalność i lokowane produkty. Przedstawianie pozytywnych opinii na temat oferowanych produktów jest jednym z założeń aspektu poznawczego blogóu. Drugie założenie to budowanie takiego wizerunku autora, który upływa na zdobycie zaufania i pozyskanie jak największej liczby osób odwiedzających blog. Styl blogów jest bardzo zróżnicowany tematycznie i indywidualnie, a jego głóunym celem jest zrealizowanie założeń pragmatycznych i poznawczych.
\end{abstract}

Słowa kluczowe: blog, gatunek tekstu, hipertekst, komunikacja internetowa, internet.

\section{Blog as a genre of text in the context of content monetization}

\begin{abstract}
A Blog is a hypertext genre with a large span of pattern in structural, pragmatic, cognitive and stylistic terms. This is due to its short history and large changes in Internet communication. The author of the blog must publish articles regularly for a long time to make money thanks to the blog. It introduces many modifications to the quality standard in order to match its activities. The most pronounced changes relate to the structure of the genre and include the addition of advertisements, sponsored articles, activation links and separate cards on the website (e.g. training, workshops, camps and shop). There is a strong influence of advertisers or principals who indirectly participate in the process of creating the text and assume the role of the message controller. Author's message is more likely than other blogs to be persuasive to promote their own activities and products. Presenting positive feedback on the products offered is one of the assumptions of the cognitive aspect of blogging. The second assumption is to build such an image of the author, which influences gaining confidence and acquiring as many visitors
\end{abstract}


as possible to the blog. The style of blogging is very varied thematically and individually, and its main purpose is to realize pragmatic and cognitive assumptions.

Keywords: blog, text genre, hypertext, internet communication, web.

\section{Wprowadzenie}

Blog jest gatunkiem hipertekstowym ${ }^{1}$, tworzonym w środowisku www i pouszechnie występującym w komunikacji internetowej. Uznaje się, że początkowo zastąpił formy pamiętnikarsko-dziennikowe znane z formy pisanej i drukowanej ${ }^{2}$. Pierwotnie wpisy na blogu miały wymiar indywidualny, były datowane i prezentowane w porządku chronologicznym. Ten porządek chronologiczny, oprócz możliwości dopisywania komentarzy do poszczególnych wpisów przez internetouych czytelników i wpływania na kształt publikacji, stanowił podstawowy wyróżnik blogu jako gatunku3. W pewnym okresie duże platformy internetowe zachęcały internautów do zakładania nowych dzienników internetowych (np. blog.interia, blog.onet, mylog) i oferowały im gotowe interfejsy blogowe, które wprowadzały podstawowe porządkowanie i segregowanie upisów właśnie w układzie chronologicznym.

Szybki rozwój mediów elektronicznych w połączeniu z modą sprawiły, że gatunek ten bardzo się rozpowszechnił, a nowo poustałe narzędzia interfejsu graficznego (w tym tagowanie i dokładanie kolejnych kart i zakładek) wraz z potrzebami i pomysłowością użytkowników zmieniały pierwotny charakter blogów poprzez dodawanie obsługiwanych funkcjonalności oraz rozszerzanie tematyki i autorskich

\footnotetext{
${ }^{1}$ W polskiej literaturze językoznawczej koncepcję hipertekstu przedstawił m.in. Marcin Maciejeuski w książce Gatunki hipertekstu w perspektywie tekstologicznej. Analiza na przykładzie internetowych prezentacji przedsiębiorstw, Wydawnictuo Naukowe UAM, Poznań 2009; Bożena Witosz w artykule Lingwistyczne koncepcje tekstu wobec wyzwań komunikacji wirtualnej, w: Tekst (w) sieci 1. Tekst, język, gatunki, red. D. Ulicka, Wydawnictua Akademickie i Profesjonalne, Warszawa 2009, s. 15-26 oraz Jerzy Bartmiński i Stanisława Niebrzegouska-Bartmińska u rozdziale Hipertekst książki Tekstologia, Wydawnictwo Naukowe PWN, Warszawa 2012. Z punktu widzenia literaturoznawczego bardzo obszerne opracowanie na temat hipertekstu przedstawił Mariusz Pisarski w książce Xanadu: hipertekstowe przemiany prozy, Korporacja Ha!art, Kraków 2013. Wcześniej zagadnienia hipertekstowe były prezentowane u postaci hipertekstu na stronie www.techsty.art.pl w zakładce Hipertekst (dostęp: 9.11.2019).

2 A. Gumkouska Blogi wobec tradycji diarystycznej. Nowe gatunki w nowych mediach [w:] Tekst (w) sieci, t. 1 op. cit., s. 231-243. Krótką historię bloga przedstawia Maciej Maryl w artykule Blog jako „dziennik elektroniczny”. Analiza genologiczna blogów pisarzy, „Zagadnienia Rodzajów Literackich" 2013, z. 2, s. 87-110.

${ }^{3}$ Marta Więckiewicz uznaje chronologiczny układ upisów za podstawowy wyznacznik bloga, pisząc, że blog to „dokument osobisty, składający się z datowanych wpisów prezentowanych u kolejności odwrotnej od chronologicznej, publikowany przez blogera na stronie internetowej” (eadem, Blog w perspektywie genologii multimedialnej, Wydawnictuo Adam Marszałek, Toruń 2012, s. 64). O istocie komentarzy w blogach pisali Jan M. Zając, Kamil Rakocy i Andrzej Nowak u artykule Interaktywne, choć osobiste blogi i blogowanie a komunikacja z otoczeniem [w:] Tekst (w) sieci, t. 1, op. cit., s. 219-229.
} 
celów ${ }^{4}$. Do początkowych wątków emocjonalno-indywidualnych dołączyły wątki tematyczne i eksperckie, polityczne, dziennikarskie, instytucjonalne, celebryckie, a także biznesowe ${ }^{5}$. Ludzie już nie tylko uzewnętrzniali się przed sieciową społecznością, odkrywali swoje emocje, indywidualne przeżycia i przemyślenia, ale także włączali do tej formy najróżniejsze treści, z których duża część miała służyć upływaniu na odbiorców poprzez uskazywanie wzorców i kształtowanie ich opinii. Równolegle jako jeden z blogowych wątków pojawiła się szeroko pojęta działalność biznesowa i próby zarabiania poprzez prowadzenie bloga. Odbywa się to poprzez poruszanie zagadnień ekonomicznych lub, znacznie częściej, uykorzystanie dowolnego bloga o określonej tematyce do generowania zysków przez odpowiednie działania marketingowe oraz modyfikowanie u tym celu treści przekazu.

\section{Monetyzacja bloga}

Intensywność przekazów internetowych na przełomie XX i XXI wieku znacząco wzrosła i ludzie dostrzegli potencjał marketingowy tego kanału komunikacji. Coraz popularniejsze i masowo odwiedzane blogi zaczęły początkowo być dobrym nośnikiem reklamy, podobnie jak działo się to dotąd z prasą․ W dalszej kolejności aktywność blogerów, oprócz możliwości publicznego wypowiadania się, zyskiwania popularności i kontaktu z użytkounikami sieci internetowej, pozwoliła także na zarabianie na treści suoich przekazów. Wiązało się to z funkcją opiniotwórczą poczytnych wpisów, w tym kreowania wzorców, mód i stylu życia oraz promowaniem poprzez artykuły zamieszczane na blogu produktów (własnych lub pochodzących od zleceniodawcy)?

4 Zmiany rozwojoue doprowadziły do tego, że uspółcześnie blog (i jego pojedynczy upis), podobnie do profilu na Facebooku i wielu innych gatunków medialnych, korzysta ze zbliżonych lub nawet tych samych środków i form uyrazu, przez co trudno jednoznacznie uskazać uyraźnie odmienne cechy każdego z tych gatunków. Pisała o tym Sara Akram: „Wydaje się, że najbardziej uspółczesne formy wypowiedzi medialnych, a zułaszcza internetouych, są na tyle heterogeniczne, że trudno jest ustalić granice poszczególnych gatunków oraz zależności między nimi” (eadem, Blog - gatunek w formie kolekcji czy kolekcja gatunków?, „Acta Humana” 2017, nr 8, s. 67). Podobne refleksje w relacji blogu i osobistej strony internetowej przedstawia Anna Rogozińska (eadem, Osobista strona internetowa [w:] Od aforyzmu do zinu. Gatunki twórczości słownej, red. G. Godlewski [et al.], Wydawnictua Uniwersytetu Warszauskiego, Warszawa 2014, s. 319-325.

${ }^{5}$ Odmiany blogów zostały przedstawiane w następującym artykule: M. Maryl, K Niewiadomski,. M. Kidawa, Teksty elektroniczne w działaniu: typologia gatunków blogowych, „Zagadnienia Rodzajów Literackich” 2016, nr 2, s. 51-72. Wątek ten porusza także M. Więckiewicz u swojej książce poświęconej blogom (idem, op. cit., s. 126-166).

${ }^{6}$ Pisze o tym Leszek Olszański w swoich dwóch książkach Dziennikarstwo internetowe, Wydawnictua Akademickie i Profesjonalne, Warszawa 2006, s. 42 oraz Media i dziennikarstwo internetowe, Wydawnictwo Poltex, Warszawa 2012, s. 26.

${ }^{7}$ Wpisy na blogach służą promocji marketingowej, aby osiągnąć cele wizerunkoue i sprzedażowe, o czym pisali Grzegorz Mazurek, Blogi i wirtualne społeczności - wykorzystanie w marketingu, Oficyna Wolters Kluwer Polska, Kraków 2008; idem, Znaczenie wirtualizacji marketingu w sieciowym kreowaniu wartości, Wydawnictwo Poltex, Warszawa 2012; Marta Gregory, Serwisy społecznościowe jako narzędzie marketingowe, „Zeszyty Naukoue 
Wraz z pojawieniem się portali społecznościowych, takich jak Facebook, Instagram, Twitter czy YouTube, doszło do sytuacji, w których już nie tylko blogi stały się udziałem publikacji internetowej przez użytkowników. Obecnie większość działalności sieciowej poza blogiem wykorzystuje dodatkowo właśnie te media społecznościowe, a treści w nich zawarte równocześnie poutarzają się i uzupełniają.

Istnieje co najmniej kilka form zarabiania dzięki prowadzeniu bloga. Rozbudowane informacje o takich możliwościach prezentują dziś nie kto inny, jak sami blogerzy, pisząc na ten temat osobne posty oraz przygotouując materiały w postaci podcastów czy filmów ${ }^{8}$. Zaawansowani autorzy są także autorami książek na ten temat ${ }^{9}$. Bardziej skrótowe informacje można wyczytać na finansowych stronach internetowych ${ }^{10}$. Według tych źródeł istnieje wiele form, z których korzystają prywatni blogerzy. Są to: reklamy, banery, artykuły sponsorowane, programy afiliacyjne, uspółpraca z ekspertami, wypuszczanie i sprzedaż własnych produktów, przeprowadzanie dedykowanych kampanii z partnerami, występy na konferencjach, prowadzenie szkoleń stacjonarnych i online oraz konsultacje indywidualne ${ }^{11}$.

\section{Metodologia i cel badania}

W artykule podjęto szczegółowe zagadnienie dotyczące bloga jako gatunku tekstu w ujęciu genologii linguistycznej. Za gatunek tekstu w tej perspektywie badawczej należy uznać abstrakcyjny wzorzec (realizowany w wielu wariantach) obejmujący zbiór reguł organizacji gatunkouego schematu ${ }^{12}$. W zależności od ujęcia badauczego określa się tu wiele poziomóu organizacji, na przykład strukturalny, pragmatyczny, poznawczy i stylistyczny, znany z prac Marii Wojtak ${ }^{13}$, czy też etnolingwistyczne ujęcia postulowane przez Jerzego Bartmińskiego i Stanisławę Niebrzegowską-Bartmińską, obejmujące: obraz nadawcy i odbiorcy powiązanych intencją komunikacyjną, relację tekstu werbalnego do sytuacji komunikacyjnej, obecność kodów niewerbalnych, kreowany obraz świata, konstrukcję miejsca i czasu oraz sposób językowego konstruowania tekstów ${ }^{14}$.

Uniwersytetu Szczecińskiego” 2011, nr 656, s. 35-47; Bogdan Gregor i Dominika Kaczorouska-Spychalska w artykule Blogi jako instrument strategii promocji on-line, „Zeszyty Naukoue Uniwersytetu Szczecińskiego" 2014, nr 829, s. 17-29.

8 Np. https://rekinfinansow.pl/jak-zarabiac-na-blogu czy https://jakoszczedzacpieniadze.pl/ jak-zarabiac-na-blogu-poradnik (dostęp: 20.09.2019).

9 Patrz: M. Szafrański, Zaufanie, czyli waluta przyszłości: moja droga od zera do 7 milionów z bloga, Grupa Wydawnicza Relacja, Warszawa 2018.

${ }^{10}$ Np.: https://poradnikprzedsiebiorcy.pl/-jak-zarabiac-na-blogu (dostęp: 20.09.2019).

11 Informacje pochodzą ze wspomnianych ucześniej blogów: https://jakoszczedzacpieniadze. pl/wnop-015-zarabianie-na-blogu-czesc-1 (dostęp: 20.09.2019); https://rekinfinansou.pl/jak-zarabiac-na-blogu/ (dostęp: 20.09.2019). Dodatkowo można też uskazać kolejne trzy sposoby, są to: użyczenie wizerunku, usparcie marketingowe dla innych i sprzedaż warsztatu blogera.

${ }_{12}$ M. Wojtak, Gatunki prasowe, Wydawnictuo Uniwersytetu Marii Curie-Skłodouskiej, Lublin 2004, s. 16.

${ }^{13}$ Ibidem, s. 16-17.

14 J. Bartmiński, S. Niebrzegouska-Bartmińska, op. cit., s. 133-134. 
Ujęcia genologiczne nawiązują do literaturoznawczych prac Michaiła Bachtina, który definiował gatunki jako „konkretne, względnie trwałe pod uzględem tematycznym, kompozycyjnym i stylistycznym typy wypouiedzi, które kształtują się w zależności od funkcji oraz specjalnych, właściuych każdej sferze, okoliczności obcowania językowego" ${ }^{15}$. Współcześnie koncepcje literaturoznawcze i językoznawcze poszerza się o dodatkowe elementy kształtowane przez nowoczesne media, zawierające złożone i kolorowe grafiki, obrazy, wideo oraz dźwięki ${ }^{16}$.

Istotą tego opracowania jest skorelowanie funkcji biznesourych prywatnego blogu z wzorcem gatunku hipertekstowego ${ }^{17}$, jakim jest blog. Wstępne obserwacje dają podstauy do tego, by postawić tezę, że taka zależność istnieje i zarabianie poprzez prowadzenie bloga upływa na jego kształt i wymowę. Za podstawę metodologiczną przyjmuję ujęcie genologiczne Wojtak, która uydzieliła cztery uspomniane już aspekty organizacji wzorca gatunkowego ${ }^{18}$. Moim zadaniem jest zaobserwowanie, czy i w jaki sposób elementy działań biznesowych prowadzonych w ramach bloga wpływają na jego postać gatunkową. Analiza będzie dotyczyć poszczególnych aspektów, które składają się na całość opisu genologicznego, czyli strukturalnego, pragmatycznego, poznawczego i stylistycznego. W odniesieniu do każdego z nich zostaną przedstawione dające wyodrębnić cechy charakterystyczne właściue dla podjętych działań zarobkowych.

${ }^{15}$ M. Bachtin, Problem gatunków mowy [w:] idem, Estetyka twórczości stownej, przel. E. Ulicka, Państwowy Instytut Wydawniczy, Warszawa 1986, s. 348-402. Bogactuo podejść badauczych nad gatunkami, które doprowadziły do współczesnego stanu wiedzy, można zaobserwować m.in. w częściach teoretycznych większych ostatnich prac genologicznych, np. M. Maciejewski, op. cit., s. 79-93.

${ }^{16}$ Połączenie elementów werbalnych z obrazami i dźwiękiem dało początek poustaniu genologii multimedialnej. Twórcą terminu jest Edward Balcerzan: idem, $W$ stronę genologii multimedialnej, „Teksty Drugie” 1999, nr 6, s. 7-24. Do multimedialnego opisu gatunków nawiązują m.in. prace: B. Witosz, op. cit.; L. Olszański, Dziennikarstwo internetowe..., op. cit.; idem, Media i dziennikarstwo internetowe..., op. cit; M. Maciejewski, op. cit; M. Więckiewicz, op. cit.; Wspótczesne media: gatunki w mediach elektronicznych, red. I. Hofman, D. Kępa-Figura, Wydaunictwo Uniwersytetu Marii Curie-Skłodowskiej, Lublin 2017; I. Loewe, Dyskurs telewizyjny w świetle lingwistyki mediów, Wydaunictuo Uniwersytetu Śląskiego, Katowice 2018; E. Topolnicka, Estetyka strony internetowej [w:] Zielonogórskie Seminaria Językoznawcze 2018: Estetyka jezzykowa w komunikowaniu, red. M. Kaczor, M. Steciąg, Oficyna Wydaunicza Uniwersytetu Zielonogórskiego, Zielona Góra 2019, s. 227-236. Ze względu na wzrastający udział form niewerbalnych i nowych mediów w komunikacji multimedialność staje się coraz częstszym przedmiotem badań genologicznych. Wciąż obserwuje się kształtowanie i rozwój metodologicznego podejścia do badań tekstów i gatunków z uwzględnieniem ich multimedialności. Dostrzega się u nich coraz większe znaczenie strony technicznej, o czym można przeczytać u tomie Przekaz digitalny. $Z$ zagadnień semiotyki, semantyki i komunikacji cyfrowej, red. E. Szczęsna, TAIWPN Universitas, Kraków 2015 oraz w książce Euy Szczęsnej (eadem, Cyfrowa semiopoetyka, Instytut Badań Literackich PAN, Warszawa 2018).

${ }^{17}$ Według Maciejeuskiego gatunek hipertekstu jest ujmowany jako „prototypowa konstrukcja tekstowa, która [...] poustaje, podobnie jak tekst linearny, jako wynik pewnych kognitywnych procesów, odnoszących się do konkretnych tekstów i ich cech" (idem, op. cit., s. 116).

${ }^{18}$ M. Wojtak, op. cit., s. 18. 
Aby uzyskać odpowiedź na postawioną tezę, uybrano podstawę materiałową, którą stanowi pięć blogów o różnej tematyce: fotograficzno-podróżniczy Mammamija.pl ${ }^{19}$, sportowy: WarszawskiBiegacz.pl ${ }^{20}$, podróżniczy: Globstory ${ }^{21}$, parentingouy: Oczekując. $\mathrm{pl}^{22}$ oraz lifestylowy: AgnieszkaMaciąg.pl ${ }^{23}$. Podczas lektury notowano wszelkie przejawy prowadzonej działalności biznesowej. Ekscerpowany materiał pochodzi w większości z wpisów ostatniego roku. Sposoby tematycznego przeszukiwania zawartości blogów poprzez zastosowane przez autorów odnośniki hipertekstowe bardzo często prowadzą do starszych zapisów. Można zatem uznać, że obserwacji podlegał cały korpus publikowanych zapisów.

\section{Aspekt strukturalny}

Aspekt strukturalny gatunku wypowiedzi dotyczy kompozycji tekstu, części poszczególnych elementów biorących udział w jego budowie, ich wzajemnego ułożenia i relacji między nimi. Należy pamiętać, że blogi są hipertekstami i u stosunku do nich nie można przykładać tak sztyunych zasad co do kolejności układu elementów jak w tekstach tradycyjnie pisanych i drukowanych. Ponadto kolejność poszczególnych elementów daje się dość łatuo kształtować i na bieżąco uzupełniać, a to sprawia, że funkcjonuje obok siebie wiele wzorców alternacyjnych ${ }^{24}$. W przypadku treści biznesowych służących zarabianiu pieniędzy poprzez pisanie bloga należy uznać ten aspekt za najbardziej wyeksponowany i najbardziej oczywisty. Daje się go obserwować w postaci elementów dodanych do typourych elementów wzorca w porównaniu z innymi blogami. Pierwszym i najłatwiej rozpoznawanym elementem zarabiania na prywatnym blogu są reklamy. Mogą one mieć postać całych ekranów lub wyodrębnionych pól w określonych miejscach ekranu, a ich treść jest niezależna od autora ${ }^{25}$. W tej samej roli mogą wystąpić banery uyświetlające się u dołu lub u góry strony. Trzeba jednocześnie zauważyć, że odbiorcy narzekają na pojawianie się reklam, w zuiązku z czym zaawansowani blogerzy rezygnują z tej formy zarobku lub ją w znacznym stopniu ograniczają.

Kolejny element dodany w obrębie postu to reklama kontekstowa w postaci linków afiliacyjnych. Autor publikuje artykuł na określony temat i podpowiada internautom, jak można rozwiązać rozpatrywany problem (np. założenie konta bankowego, założenie lokaty, kupno określonego produktu lub usługi, spędzenie wolnego czasu, urządzenie

\footnotetext{
${ }^{19}$ http://wuw.mammamija.pl (dostęp: 9.11.2019).

${ }^{20}$ http://warszauskibiegacz.pl (dostęp: 9.11.2019).

${ }^{21}$ http://wuw.globstory.pl (dostęp: 9.11.2019).

${ }^{22}$ https://oczekujac.pl (dostęp: 9.11.2019).

${ }^{23}$ http://agnieszkamaciag.pl (dostęp: 9.11.2019).

${ }^{24}$ Pojęcia wzorca alternacyjny obok kanonicznego i adaptacyjnego uprowadziła Maria Wojtak. Wzorce alternacyjne „poustają w wyniku przekształcenia poszczególnych składników wzorca kanonicznego" (eadem, op. cit., s. 18).

${ }^{25}$ Tuórca bloga uyraża jedynie zgodę na określony rodzaj reklam. Szczegółowe uypełnienie reklam treściami zależy od prowadzonych w danym czasie kampanii reklamouych. Autor bloga może częściowo określać, jakie branże mają uypełniać przestrzeń reklamową.
} 
unętrza). W tekście lub na końcu akapitu lub też na końcu tekstu znajduje się odesłanie do stron oferujących przedstawiane wcześniej towary czy usługi (1). Czasami funkcję linków uzyskują pojedyncze uyrazy umieszczone w obrębie publikowanego tekstu. Ich sens łączy się z zakresem reklamowanego produktu. Post bloga jest wtedy pozornie pozbawiony zewnętrznych odsyłaczy, jednak zawiera wyróżnienie hipertekstowych węzów u postaci koloru lub podkreślenia, a najechanie znacznikiem na taki link wykazuje jego aktywność hipertekstową (kliknięcie kieruje do strony z reklamowaną treścią). Formę pośrednią przyjmują zapisy, w których autor na przykład przypomina, że omawiał już ten problem u swojej książce i podaje jej tytuł, będący jednocześnie odsyłaczem do strony serwisu zakupowego (2).

(1) Wiem, że z pewnością będą pytania: co, gdzie i za ile? Więc niżej zostawiam namiary na nasze dekoracje. Przed nami zabawy karnawałowe, imprezy domowe, kolejne urodziny, więc można się inspirować (:)

Zastawa porcelanowa Kolekcja Porcelany MariaPaula Ecru Queen - TUTAJ

Komplet sztućców Gerpol TUTAJ

Dodatki: złote gwiazdy, złoty wianek, złota choinka, złote świeczniki Home \& You TUTAJ Podkładki, lampki KIK TUTAJ

[https://oczekujac.pl/2019/01/stol-wigilijny-na-zloto.html; dostęp: 6.09.2019].

(2) Tak głosi stare chińskie przysłowie, które stało się jednym z najważniejszych zdań mojego życia. Można je odnaleźć na przykład u mojej książce „Pełnia życia” - opisałam je tam jako jeden z głóunych filarów tworzenia szczęścia i spełnienia [http://agnieszkamaciag. pl/scenariusz-szczesliwego-zycia-wazne-narzedzie-rozwoju/; dostęp 20.09.2019].

Posty z artykułami sponsorowanymi to następne dodawane do bloga elementy. Zawierają one informację, że publikacja jest sponsorowana. Przykładem może być opis doboru opon do samochodu na blogu parentingowym Oczekując.pl (3). Pojawia się pytanie, czy taki odcinek bloga zostałby zamieszczony, gdyby nie wkład sponsora, a z peunością bez udziału czynników zeunętrznych jego treść i kształt uygglądałyby inaczej. Dlatego można powiedzieć, że działalność biznesowa na blogu dzięki artykułom sponsorowanym generuje dodatkowe upisy o określonym charakterze. Więcej uwag na ten temat znajdzie się $\mathrm{w}$ opisie aspektu poznawczego bloga.

(3) Partnerem upisu jest marka Continental, producent opon premium [https://oczekujac. pl/2019/04/czy-twoj-maz-na-wiosne-tez-rozglada-sie-za-zdrowymi-osiemnastkami-i-bardzo-dobrze.html; dostęp: 9.09.2019].

Blogi, dzięki którym ich twórcy zarabiają, są rozbudowane na tle innych. Aby działalność przynosiła zysk, trzeba pisać regularnie, a to przyczynia się do podejmowania kolejnych tematów i obszarów wiedzy. Stąd już pierwsze dodatkowe podziały na szczegółowe tematy i zakresy zagadnień widoczne w postaci rozbudowanego menu ${ }^{26}$,

${ }^{26}$ Blog parentingowy Oczekując.pl doczekał się następujących kart bloga: Mama, Tata, Dziecko, Ciąża, Kuchnia, Zdrowie i uroda, Porady, Podróże i Wnętrza. Początkowe upisy twórczyni 
liczby wewnętrznych odsyłaczy do innych wpisów, wykorzystanych tagów ${ }^{27}$ oraz przekierowań zewnętrznych. Szczególnie eksponowane miejsce zajmują dodatkowe karty o charakterze biznesowym w menu. Są one umieszczone na panelu górnym i dostęp do nich jest bezpośredni przez cały czas przeglądania bloga. Liczba kart zależy od zakresów podjętych działań, a ich układ jest wynikiem uykorzystanego szablonu. Obserwuje się tu róunież zmiany u czasie wraz z rozwojem pracy blogera. Typowym przykładem jest rozszerzenie elementów strony o kartę prowadzonego sklepu lub innej formy dystrybucji (np. sklep zewnętrzny ${ }^{28}$ ), jeżeli autor decyduje się na taką działalność. Podobnie osoby będące ekspertami u jakiejś dziedzinie oferują warsztaty, szkolenia lub uspólne obozy. Na łamach poszczególnych kart widnieją informacje o aktualnych lub ostatnich takich przedsięwzięciach i możliwościach zapisu na nie.

Charakterystyczna dla pozyskiwania źródeł finansowych jest także dodawana karta Współpraca. W niej mogą znajdować się jedynie deklaracje o chęci uspółpracy i odesłanie do strony kontaktowej ${ }^{29}$ lub też karta jest bogatsza $w$ informacje i dodatkowo służy budowaniu pozytywnego wizerunku, na przykład poprzez uskazywanie na korzyści dla ewentualnych sponsorów z podjętej z autorami bloga uspółpracy i odwołaniu się do doświadczenia zarówno w zakresie podejmowanego tematu na blogu, jak i w kampaniach marketingowych. Dlatego też publikowane są tu dane statystyczne o liczbie tzw. unikalnych użytkowników (także analogiczne dane z innych social mediów), ruchu na stronie, a czasem również dane ankietowe dotyczące odbiorców (ich wiek, płeć czy rozmieszczenie geograficzne). Bardziej zaawansowani uymieniają nazuy firm, dla których realizowali swoje kampanie. Treści służące budowaniu własnego wizerunku mogą mieścić się u tej jednej karcie, ale też mogą zostać rozszerzone o kolejną kartę, jak to się dzieje we wspomnianym już blogu parentingowym Oczekując.pl. Wprowadzono tu kolejną kartę Media i umieszczono w niej kilkadziesiąt zrzutów ekranu z programów telewizyjnych, w których autorzy wystąpili, oraz linki do telewizyjnych, radiouych i prasowych materiałów z ich udziałem lub na ich temat.

Nową formą pozyskiwania pieniędzy do własnych przedsięwzięć jest poszukiwanie patronów, czyli osób lub instytucji wspierających blogera comiesięcznymi datkami. Forma ta ujaunia się kolejną kartą zatytułowaną Patronite wymieniającą wszystkich

(Mama) zostały u pewnym momencie uzupełnione o upisy jej męża (Tata), a rozrost tematyki doprowadził do wprowadzenia nowych kart.

27 Michał Szafrański na suoim blogu Jak oszczędzać pieniądze? (https://jakoszczedzacpieniadze. pl/) w karcie Spis treści zamieszcza odnośniki do ostatnich 500 przygotowanych artykułów. Każdy z ponumerowanych tytułów jest jednocześnie linkiem przenoszącym. Karta owa ma również linki do ponad trzydziestu tematów podejmowanych na blogu.

${ }^{28}$ Do sklepu zewnętrznego prowadzi np. blog Agnieszki Maciąg, która firmuje świece zapachowe dystrybuowane przez sklep blogu SanNamLife prowadzonego przez Malwinę Kowalską-Łaskauską. Tenże blog owej autorki jest także wykorzystywany do realizacji innych działalności biznesouych Agnieszki Maciąg, u tym spotkań i warsztatów.

${ }^{29}$ Przykładem może być blog Mammamija.pl, który zawiera u tej karcie bardzo oszczędne informacje. 
dotychczasouych darczyńcóu i odsyłającą do serwisu o tym tytule. W nim można poznać szczegółowo potrzeby autora i zdeklarować własny udział w jego przedsięuzięciu ${ }^{30}$.

\section{Aspekt pragmatyczny}

Pragmatyka obejmuje relacje nadawczo-odbiorcze zachodzącej komunikacji oraz intencje uczestników biorących w niej udział i skutki, jakie wywołuje. Pozornie przekaz na zuykłym blogu niewiele się różni od tego, który służy zarabianiu pieniędzy. Ten sam autor wciąż realizuje funkcję komunikacyjną, gdyż zuraca się poprzez swój sieciouy dziennik do tych samych odbiorców, może czytać ich komentarze i na nie reagować, co czasem prowadzi do rozbudowanej interakcji. Publikowaniu postów zausze towarzyszy jakiś przewodni cel od ekspresywnego odkrywającego emocje twórcy, przez rozrywkowe, po informacyjne i edukacyjne, w których bloger występuje jako przewodnik lub ekspert. Motyw merkantylny działalności blogerskiej wprowadza dodatkowy róunoległy i być może podstawowy dla autora cel takiej komunikacji, bo jej istotą nie jest już uyłącznie dzielenie się przeżyciami, dośuiadczeniami czy wiedzą, lecz chęć pozyskania z tego profitów finansowych ${ }^{31}$. Z punktu widzenia użytkounika internetu dominujący jest cel pierwotny, związany z tematyką autorską, sposobem przekazu i jego osobą. Zbyt wyraźne odkrywanie celu biznesowego, w którym odbiorca internetouy jest narzędziem, może go zrazić i spowodować niechęć do dalszej lektury.

Pisanie bloga według zaleceń praktyków powinno łączyć się z pasją przedstawienia podjętego tematu. Decyzja o przeznaczeniu zarobkowym bloga zmienia tę sytuację i pierwotny zapał, przekształca się w dużej mierze u pracę i obowiązek, które wymagają konsekwencji i regularności w przygotowywaniu i publikowaniu coraz to nowych materiałów ${ }^{32}$. Wynika to z prostej zależności, według której zysk zależy od popularności i ruchu na stronie bloga (liczba unikalnych użytkowników, liczba odsłon, czas pozostawania na stronie, kliknięcia w linki aktywacyjne), więc autorom zależy na uatrakcyjnieniu przekazu i podejmowaniu przyciągających tematów ${ }^{33}$.

\footnotetext{
${ }^{30}$ Blog podróżniczy Globstory (https://globstory.pl) wymienia ok. 300 patronów i przedstawia cel miesięczny u wysokości 8888 zł (wrzesień 2019 r.). Decydując się na pomoc, można uybrać kuotę 5, 10, 20, 50, 100, 300 lub 1000 zł. Każdy z patronów otrzymuje od autora coś dodatkowego, np. przy kwocie 300 zł pada deklaracja osobistego spotkania przy kawie i uspólne dyskusje, a przy kwocie 100 zł otrzymuje się kartki pocztowe z miejsc podróży oraz można zostać uymienionym na końcu materiału filmowego.

31 Nawet jeśli głównym celem blogu staje się zarabianie pieniędzy, to musi u nim pozostać także jakiś inny cel, na którym zasadza się treść przekazu i kształtują relacje nadawczo-odbiorcze. Z tych ułaśnie powodów użytkownicy internetu sięgają po blogi.

${ }^{32}$ Tak ułaśnie zaleca u suojej książce i na swoim blogu Michał Szafrański, op. cit; https:// jakoszczedzacpieniadze.pl (dostęp: 20.09.2019).

${ }_{33}$ Autorzy, obserwując, które wątki są lepiej przyjmowane przez internautów, oraz które elementy ucześniejszych publikacji bardziej przyciągają odbiorców, mogą ukierunkouywać kolejne swoje przekazy tak, by następne wpisy miały większy odbiór i więcej pozytywnych reakcji. Część podejmowanych tematóu praudopodobnie nigdy by nie poustała, gdyby nie stymulacja marketingowa.
} 
W relacjach nadawczo-odbiorczych bloga swój udział ma reklamodawca, który płaci za pisanie o swoim produkcie, a tym samym staje się częścią autorskiego przekazu. Przy tworzeniu artykułów sponsorowanych autorzy korzystają z tekstów promocyjnych zleceniodawcy, szczególnie przy doborze treści i uyrażaniu opinii o produkcie (np. nowoczesność i bezpieczeństuo przy technice, moda i trendy przy modzie) ${ }^{34}$. Ponadto uspółcześnie media elektroniczne zawierają wiele zdjęć i filmów. Na nich z kolei pojawiają się promowane i lokowane produkty z logo firmy. Autorski udział w tych przekazach róunież należy przypisać reklamodawcy.

Kolejny istotny wkład zleceniodawcy u przekazie bloga polega na kontroli publikowanych artykułów (gate-keeping). Jego celem jest uwiarygodnienie przekazu poprzez przerzucenie promocji produktu na autora bloga ${ }^{35}$. Relacje te nie są ujauniane, ale trudno sobie wyobrazić wysokie wynagrodzenie za negatywną opinię. Autorzy często zastrzegają sobie u karcie Wspótpraca możliwość uyboru, z kim podejmą uspółpracę biznesową, oraz prawo do osobistych opinii, nawet nie zausze pochlebnych. Obseruruje się jednak, że przedstawiane produkty są przeważnie opisywane pozytywnie ${ }^{36}$.

Postom blogerów towarzyszą komentarze internautów. W dobrych blogach najwięcej jest opinii pozytywnych (4). W sytuacji, gdy artykuł sponsorowany nadmiernie promuje jakiś produkt, mogą pojawić się negatywne i demaskujące reakcje internautów (5).

(4) Świetne porady! Widać, że wiesz, o czym piszesz. To rodzaj postu który może inspirować wyjazdu - lub przyczyniać się do tego, żeby faktycznie dochodzily do skutku. Dzięki! [https:// globstory.pl/jordania-w-tydzien-lub-dluzej-mapka/; dostęp: 20.09.2019].

(5) Glupoty az zygac sie chce. Reklama fotelika. Dziecko 5 letnie w foteliku zapiete pasami samochodowymi. I niby dobrze zabezpieczone [https://oczekujac.pl/2019/08/jedziesz-na-wakacje-koniecznie-przeczytaj.html; dostęp: 20.09.2019].

\section{Aspekt poznawczy}

Aspekt poznawczy (zwany też kognityunym) odnosi się do podejmowanej tematyki i wizji świata, który się przedstawia. Po części też może wiązać się z najważniejszymi sposobami przedstawiania treści. W przypadku bloga trudno uskazać jakąś ograniczoną czy choćby główną treść przypisaną do gatunku, ponieważ przykłady zaświadczają pełną otwartość treściową. Mimo wszystko można pokusić się o podstawową uwagę

\footnotetext{
${ }_{34}$ Wizerunek produktu $u$ artykule sponsorowanym jest zgodny z treściami reklamami. Treść reklamy najczęściej projektuje ogólny sens wpisu bloga, a autor dokłada swój wizerunek i swoją historię zuiązaną z promowanym produktem. Blogi o tematyce technicznej bardzo często silnie korespondują z materiałami producenta, czasem je wręcz powielają. Tylko najlepsi eksperci są u stanie przeprowadzić własne analizy i zueryfikować treści reklamowe.

${ }_{35}$ Pisze o tym Grzegorz Mazurek u artykule Ewolucja wykorzystania mediów społecznościowych w marketingu, „Nierówności Gospodarcze a Wzrost Gospodarczy” 2016, nr 1, s. 23-31. ${ }^{36}$ Pozytyuny opis produktu na popularnym blogu może przynieść korzyść finansouą autorowi i perspektywę dłuższej współpracy, ale wyżej cenione, przynajmniej przez internautóu, są opinie na blogach, które nie tylko chwalą, lecz równie często krytykują - wtedy silniejsze jest poczucie obiektywności przekazu.
} 
dotyczącą zakresu poznawczego blogerów zarabiających swoimi wpisami. Autor musi być wiarygodny w swoim przekazie, budować swój określony wizerunek tak, by odbiorcy chętnie do niego wracali. Budowanie autentyczności, wiarygodności i silnej pozycji odbywa się na wiele sposobów. Najłatwiej jest pokazać wzorce eksperckie, słowem autor bloga musi się znać na bardzo wielu zagadnieniach i przeuyższać bądź przynajmniej dorównywać innym w danej branży. Kolejny wzorzec wiąże się oryginalnością, czyli podejmowaniem nowych tematów lub na przykład opisami wypraw do miejsc, w których inni jeszcze nie byli. Następna oczekiwana cecha to autentyczność, opisywanie własnych doświadczeń i przeżytych historii, zamieszczanie suoich zdjęć. Dla innych ludzi autor staje się świadkiem i przewodnikiem podpowiadającym, jaki produkt uybrać, jak rozwiązać pewien problem i jak uniknąć peunych trudności. Autentyczność może także wiązać się z interesującym (może nawet ekshibicjonistycznym) ujawnianiem swoich poglądów i przeżyć, a twórca staje się w ten sposób przewodnikiem świata wewnętrznego człowieka.

Do tych cech należy także dodać sposób przedstawiania podjętego zagadnienia. Powinno być prosto i atrakcyjnie, dzięki temu zrozumiale i przyjemnie. Przewagę mają osoby z łatwością wyrażające sue myśli i tak dobierające słowa, by inni chcieli przeczytać kolejny post. Od pewnego czasu istnieje moda na storytelling, czyli nadawanie swej narracji postaci przyciągającej historii. Takie obrazowanie daje szansę na przyciągnięcie klienta do siebie i sugestywne przekonania go do tego, by wypróbował produkty opisywane $w$ artykule sponsorowanym i wskazane $w$ linku aktywacyjnym (6). Autor treści internetowych dzięki swojemu wpływowi i pozycji staje się influencerem, czyli kimś, kto wskazuje trendy. W przypadku udziału w kampanii marketingowej inicjatywa twórcza prywatnego blogera jest częściowo ograniczona, ponieważ jest ona zgodna ze strategią podmiotów, których produkty się promuje (7).

(6) Ludzie! Opona to jedyny łącznik całej tej maszyny, samochodu twego, ze światem zeunętrznym. [...] Oglądam u sieci mnóstuo filmików z kamer pokładouych samochodów - ogrom wypadków, kolizji, tragedii ewidentnie wynika z fatalnego stanu ogumienia! Co z tego, że u aucie jest sprawny, mocny silnik, co z tego, że ma zadbane hamulce, wymieniony olej, ładne dywaniki wewnątrz i zapachową choinkę, a! no i obowiązkowo ledy, światła ledowe muszą być. To wszystko jest ważne i fajne, ale... nie uchroni kieroucy i pasażerów przed uylądowaniem w rowie na łuku, albo na tyle innego pojazdu podczas nagłego hamowania [https://oczekujac.pl/2019/04/czy-twoj-maz-na-wiosne-tez-rozglada-sie-za-zdrowymi-osiemnastkami-i-bardzo-dobrze.html; dostęp: 20.09.2019].

(7) Długo zastanawiałam się nad kolorem. Chciałam, by nasza mała łazienka z oknem była jasnym i przyjemnym pomieszczeniem. Po głowie chodziły mi beże i szarości, ale w ostateczności zdecydowałam się na biel. Łazienka ma trochę ponad 4 metry kwadratowe i mam nadzieję, że biały kolor ją rozświetli [https://oczekujac.pl/2017/09/mala-biala-lazienka-oknem-projekt-oraz-inspiracje.html; dostęp: 20.09.2019]. 


\section{Aspekt stylistyczny}

Blogi to różnorodne teksty i trudno jednoznacznie określić ich styl. Podobny stan określa całą komunikację elektroniczną, obejmującą najróżniejsze wzorce (pisane i drukowane). Blogi mogą poustawać w rozmaitej tematyce, często specjalistycznej czy hobbystycznej, która narzuca terminologię i słownictuo środowiskowe nie uszystkim znane. Na bardzo silne zróżnicowanie stylistyczne wpływają także indywidualne preferencje autorów oraz ich umiejętności uerbalizowania przekazu.

Część wspólną stylu popularnych blogów stanowią jasność przekazu i ograniczone stosowanie słounictua specjalistycznego. Blogi również cechuje skrótowość charakterystyczna dla uspółczesnej komunikacji elektronicznej, choć u tym wypadku często ulega ona zawieszeniu na rzecz pełnego przekazu właściwego dla nurtu eksperckiego. Ponadto, jak w większości uspółczesnych przekazów sieciouych, są one nie tylko multimedialne, lecz także multimodalne, bo ich sens wynika z sumy przekazów pisanych, wielu zdjęć, a często także podcastów i filmów ${ }^{37}$. Strona graficzna najlepszych blogów jest zgodna z trendami przekazów internetowych - są one plastyczne i kolorowe, czasem też towarzyszą im efekty dźwiękowe.

Stylistyka w przypadku prywatnych blogów służących zarabianiu pieniędzy ma wymiar utylitarny i służy wzmacnianiu pozostałych aspektów, głównie pragmatycznego i poznawczego. Autor wykorzystuje znane mu środki językowe, by budować swój wizerunek i zostać uznanym za eksperta, przywódcę opinii lub kogoś wyjątkowego. Takie podejście umożliwia mu skuteczniejsze reklamowanie sprzedawanych rzeczy i oferowanych usług oraz produktów polecanych na rzecz zleceniodawców. W artykułach sponsorowanych przeważają pozytywne opinie o lokowanych produktach oraz umieszczanie ich w pozytywnym kontekście. Ponadto dobrze prowadzone blogi są wzorowo przygotowane pod względem redakcyjnym, nie zawierają błędów językouych i uprowadzają trendy graficzne. Są to profesjonalnie przygotowane materiały, nawet jeśli autor pozoruje swojskość, rodzinność czy też spontaniczność. Do publikacji trafiają uyłącznie zdjęcia u bardzo dobrej jakości. Blogi takie przygotourują grunt pod kolejne zlecenia.

\section{Podsumowanie}

Blogi są gatunkiem hipertekstowym o dużej rozpiętości wzorca w każdym z jego czterech aspektów (strukturalnym, pragmatycznym, poznawczym i stylistycznym). Jest to wynikiem historycznego kształtowania się gatunku i zmian rozwojowych w komunikacji sieciowej silnie warunkujących objęte tym kanałem przekazy.

Praktyka zarobkowa poprzez prywatny blog wymusza długotruałe i regularne publikowanie kolejnych artykułów oraz modyfikuje przyjęty wzorzec gatunkowy,

${ }_{37}$ Multimodalność polega na wykorzystaniu różnych systemów semiotycznych w jednym przekazie (por. J. Maćkiewicz, Badanie mediów multimodalnych - multimodalne badanie mediów, „Studia Medioznaucze” 2017, nr 2, s. 33-42). 
który autor dopasowuje do prowadzonych przez siebie działań. Najwyraźniejsze zmiany są dostrzegane $\mathrm{w}$ aspekcie strukturalnym $\mathrm{w}$ postaci dodawanych reklam, artykułów sponsorowanych, linków aktywacyjnych oraz osobnych kart przeznaczonych dla przyszłych reklamodawców i patronów oraz dla klientów prowadzonej przez autorów działalności biznesowej (szkolenia, warsztaty, obozy czy sklep). Pod względem pragmatycznym najuyraźniejszy jest silny upływ reklamodawców lub zleceniodawców, którzy pośrednio mogą zostać włączeni do procesu tworzenia tekstu i przyjmują rolę kontrolera przekazu, uzależniającego wynagrodzenie i dalszą uspółpracę od jakości przygotowanego materiału. Ponadto przekaz autorski częściej przyjmuje charakter perswazyjny, by promować ułasną działalność i lokowane produkty. Przedstawianie w dobrym świetle oferowanych produktów jest jednym z założeń aspektu poznawczego blogów. Drugi wiąże się z budowaniem określonego wizerunku autora, co ma upłynąć na zdobycie zaufania i pozyskać jak najwięcej chętnych do odwiedzania strony z blogiem. Styl blogów jest bardzo zróżnicowany tematycznie i indywidualnie, a jego głównym celem jest zrealizowanie założeń pragmatycznych i poznawczych.

\section{Bibliografia}

Akram S., Blog - gatunek w formie kolekcji czy kolekcja gatunków?, „Acta Humana” 2017, nr 8, s. 61-72.

Bachtin M., Problem gatunków mowy [w:] M. Bachtin, Estetyka twórczości stownej, przeł.

E. Ulicka, Państwowy Instytut Wydawniczy, Warszawa 1986, s. 348-402.

Balcerzan E., W stronę genologii multimedialnej, „Teksty Drugie” 1999, nr 6, s. 7-24.

Bartmiński J., Niebrzegouska-Bartmińska S., Tekstologia, Wydaunictwo Naukowe PWN, Warszawa 2012.

Gregor B., Kaczorouska-Spychalska D., Blogi jako instrument strategii promocji on-line, „Zeszyty Naukowe Uniwersytetu Szczecińskiego" 2014, nr 829, s. 17-29.

Gregory M., Serwisy społecznościowe jako narzędzie marketingowe, „Zeszyty Naukowe Uniwersytetu Szczecińskiego" 2011, nr 656, s. 35-47.

Gumkouska A., Blogi wobec tradycji diarystycznej. Nowe gatunki w nowych mediach [w:] Tekst (w) sieci, t. 1 Tekst, język, gatunki, red. D. Ulicka, Wydawnictwa Akademickie i Profesjonalne, Warszawa 2009, s. 231-243.

Loewe I., Dyskurs telewizyjny w świetle lingwistyki mediów, Wydawnictwo Uniwersytetu Śląskiego, Katowice 2018.

Maciejeuski M., Gatunki hipertekstu w perspektywie tekstologicznej. Analiza na przyktadzie internetowych prezentacji przedsiębiorstw, Wydawnictwo Naukowe UAM, Poznań 2009.

Maćkieuicz J., Badanie mediów multimodalnych - multimodalne badanie mediów, „Studia Medioznawcze" 2017, nr 2, s. 33-42.

Maryl M., Blog jako „dziennik elektroniczny”. Analiza genologiczna blogów pisarzy, „Zagadnienia Rodzajów Literackich" 2013 (LVI), nr 2, s. 87-110.

Maryl M., Niewiadomski K., Kidawa M., Teksty elektroniczne $w$ działaniu: typologia gatunków blogowych, „Zagadnienia Rodzajów Literackich” 2016, nr 2, s. 51-72.

Mazurek G., Blogi i wirtualne społeczności - wykorzystanie w marketingu, Oficyna Wolters Kluwer Polska, Kraków 2008. 


\section{Piotr Kładoczny}

Mazurek G., Ewolucja wykorzystania mediów społecznościowych w marketingu, „Nierówności Gospodarcze a Wzrost Gospodarczy" 2016, nr 1, s. 23-31.

Mazurek G., Znaczenie wirtualizacji marketingu w sieciowym kreowaniu wartości, Wydawnictuo Poltex, Warszawa 2012.

Olszański L., Dziennikarstwo internetowe, Wydawnictwa Akademickie i Profesjonalne, Warszawa 2006.

Olszański L, Media i dziennikarstwo internetowe, Wydawnictuo Poltex, Warszawa 2012.

Pisarski M., Xanadu: hipertekstowe przemiany prozy, Korporacja Halart, Kraków 2013.

Przekaz digitalny. $Z$ zagadnień semiotyki, semantyki i komunikacji cyfrowej, red. E. Szczęsna, Universitas, Kraków 2015.

Rogozińska A., Osobista strona internetowa [w:] Od aforyzmu do zinu. Gatunki twórczości słownej, red. G. Godleuski [et. al.], Wydawnictwa Uniwersytetu Warszauskiego, Warszawa 2014

Szafrański M., Zaufanie, czyli waluta przyszłości: moja droga od zera do 7 milionów z bloga, Grupa Wydawnicza Relacja, Warszawa 2018.

Szczęsna E., Cyfrowa semiopoetyka, Instytut Badań Literackich PAN, Warszawa 2018.

Topolnicka E., Estetyka strony internetowej [w:] Zielonogórskie Seminaria Językoznawcze 2018: Estetyka językowa w komunikowaniu, red. M. Kaczor, M. Steciąg, Oficyna Wydawnicza Uniwersytetu Zielonogórskiego, Zielona Góra 2019.

Więckiewicz M., Blog w perspektywie genologii multimedialnej, Wydawnictuo Adam Marszałek, Toruń 2012.

Witosz B., Lingwistyczne koncepcje tekstu wobec wyzwań komunikacji wirtualnej [w:] Tekst (w) sieci, t. 1. Tekst, język, gatunki, red. D. Ulicka, Wydawnictua Akademickie i Profesjonalne, Warszawa 2009.

Wojtak M., Gatunki prasowe, Wydawnictwo Uniwersytetu Marii Curie-Skłodouskiej, Lublin 2004.

Współczesne media: gatunki w mediach elektronicznych, red. I. Hofman, D. Kępa-Figura, Wydawnictwo Uniwersytetu Marii Curie-Skłodowskiej, Lublin 2017.

Zając J.M., Rakocy K., Nowak A., Interaktywne, choć osobiste blogi i blogowanie a komunikacja z otoczeniem [w:] Tekst (w) sieci, t. 1. Tekst, język, gatunki, red. D. Ulicka, Wydawnictua Akademickie i Profesjonalne, Warszawa 2009. 